\title{
Effect of age and sex on the association between lipid profile and obesity among telecomunication workers in Palembang
}

\author{
Hardi Darmawan, Irfanuddin
}

\begin{abstract}
Abstrak
Penelitian ini bertujuan mengamati pengaruh umur dan jenis kelamin terhadap berbagai kriteria obesitas dan profil lemak. Secara rinci penelitian ini menelaah obesitas tubuh secara keseluruhan (lemak tubuh, prosentase lemak tubuh dan BMI), obesitas bagian abdomen (rasio pinggang terhadap panggul, paha, dan lingkar pinggang), dan profil lipid (HDL, LDL, VLDL, total kolesterol dan triglyceride). Penelitian dilaksanakan di PT. Telkom Palembang pada tahun 2003. Sampel penelitian diwakili oleh 112 karyawan Telkom Palembang (84 pria, 28 wanita dalam kelompok usia 25, 35, 45, 55 tahun). Hasil penelitian menunjukkan: Pertama, semua hasil parameter lipid bergantung pada jenis kelamin dan umur subjek. Kedua, hubungan antara pengukuran obesitas, HDL/ LDL tidak tergantung pada jenis kelamin dan umur subyek, sedangkan hubungan antara pengukuran obesitas dan total kolesterol, VLDL, dan triglyceride bergantung pada jenis kelamin and umur subyek. Ketiga, obesitas bagian abdomen mempunyai pengaruh besar terhadap VLDL dan kadar triglyceride daripada terhadap parameter lipid lainnya. Keempat, obesitas tubuh secara keseluruhan memiliki efek yang sama terhadap seluruh parameter lipid. Apabila dibandingkan antara pria dan wanita, hasil penelitian menunjukkan bahwa pengukuran obesitas dan profil lipid pada pria lebih besar daripada wanita pada hampir semua kelompok umur, terkecuali pada subjek wanita yang berumur 45 tahun. Hal ini disebabkan obesitas abdomen dan VLDL atau triglyceride - nya lebih besar. Kelima, pengukuran obesitas dan VLDL tidak berhubungan dengan usia, sedangkan asosiasi obesitas, total kolesterol lebih kuat pada subyek yang lebih muda usianya. (Med J Indones 2007; 16:251-6)
\end{abstract}

\begin{abstract}
The study objective is to examine the effects of age and sex on the association between various obesity parameters and lipid profile. The measurements of whole body obesity (body fat, body fat \% and BMI), abdominal obesity (waist to hip ratio, waist to thigh ratio and waist circumference) and lipid profile (HDL, LDL, VLDL, total cholesterol and triglyceride) were performed on 112 telecom workers in Palembang (84 men and 28 women, age 25, 35, 45, and 55 years). All lipid parameters results depend on sex and age of subjects. The association between obesity assessments and HDL or LDL was independent of sex and age of subjects, whereas the association between obesity assessments and total cholesterol, VLDL and triglyceride is dependent on sex and age of subjects. Abdominal obesity has greater effect on VLDL and triglyceride levels than on other lipid parameters. Whole body obesity has equal effects on all lipid parameters. When comparing results of male and female subjects, obesity measurements and lipid profile association is stronger in male subjects of almost all age groups. The exception is a stronger association between abdominal obesity and VLDL or triglyceride levels in 45 years old female subjects. Obesity measurements and VLDL or triglyceride level association is independent of age, whereas obesity and total cholesterol association is stronger in younger subjects. (Med J Indones 2007; 16:251-6)
\end{abstract}

Keywords: Lipid profile, fat distribution, obesity, abdominal obesity

The relationship between obesity and health or disease has not been fully understood, however the increase risk related to obesity could be seen from the change of the lipid profile in blood. ${ }^{1}$ Statistically, male has higher risk to get heart disease as compared to female.

Department of Physiology and Biophysics, Faculty of Medicine, University of Sriwijaya, Palembang, Indonesia
This is probably enabled by the distinction of the lipid profile in the body of male and female. The blood lipid levels in the body is strongly related to the whole obesity and abdominal obesity. ${ }^{2,3}$ However, that association is probably influenced by other factors, such as age and gender which may result in subjectivity and cover the actual relation. First, the distinction of the lipid profile which related to age/ gender perhaps could be clarified by the distinction of obesity related to age/ gender. ${ }^{4}$ Second, the relation between obesity and the 
lipid profile depends on age and gender. The difference in association between obesity and the lipid profile between male and female or in age group of young and old has been reported. Only a few studies have examined the effect of age and gender in this association in random population. ${ }^{5}$ The effect of age and gender could also be distinctive depending on obesity standard used in each association. The purpose of this study is to evaluate the effect of gender and age in the association between obesity and the lipid profile in the body.

\section{METHOD}

One hundred and thirty eight employees of Regional Office of Telecom (Kandatel) age of 25, 35, 45, and 55 years participate in this study. This group is randomly selected according to sex and age group from Kandatel personnel department in 2003. The invitations to participate are sent to 138 participants and $81.16 \%$ of them come for examination.

All of anthropometric measurements are conducted according to WHO standard. ${ }^{6}$ The height is measured and rounded to the closest $0.5 \mathrm{~cm}$ where the subject is standing bare footed with the heels touching each other and the head is horizontal. The weight is measured and rounded to the closest $0.1 \mathrm{Kg}$ using RRC scale, and the subjects only use light clothing. All measurement of body circle is taken and rounded to the closest $0.5 \mathrm{~cm}$. Waist circumference is measured at the mid point between the lowest rib and iliac crest at the horizontal plane. Hip circumference is measured at the part of the hip which gives the maximum measurement over the buttocks. The thigh circumference is taken at the part which gives the maximum measurement.

BIA system analyzer TANITA, Tanita TBF-300 is the instrument used to measure bioelectrical impedance analysis (BIA) following the instruction given by the factory. ${ }^{7}$ The measurement is taken while the subjects are standing using two kinds of polarized electrode placed at the right and left feet and on the dorsal plantar of the foot. $^{8}$

Body fat and the percentage of body fat $(\mathrm{BF} \%)$ is estimated from the measurement of bioelectrical impedance using algorithm which is developed at the part of the groups from random sampling of Kandatel employees.

The waist and hip ratio (WH-ratio), waist and thigh ratio (WT-ratio) are counted from measuring waist circumference and hip and from waist circumference and thigh. Body Mass Index (BMI); body weight divided by squared of body height in meter) calculated from body weight in $\mathrm{Kg}$ and body height in meter.

Blood sample is taken after 12 hours of fasting the night before. HDL (HDL cholesterol), total cholesterol, and concentrated triglyceride $(\mathrm{mg} / \mathrm{dl})$ are analyzed from serum using enzyme method (Boehringer Mannheim, GmbH, Mannheim, Photometer 4020, Germany). Concentration of VLDL (VLDL - cholesterol) and LDL (LDL - cholesterol) calculated from triglyceride using Friedewalds's equation, only when the degree of triglyceride is below $393 \mathrm{mg} / \mathrm{dl} .^{10}$ All anthropometric measurement, obesity and blood lipid are taken on the same day.

Sex and age dependent factor were associated with the lipid profile using the correlation body fat percentage (BF\%), body mass index (BMI) correlated with lipid profile and abdominal obesity, (waist hip ratio / WHratio, waist thigh ratio / WH-ratio, and waist circumference associated with lipid profile and overall obesity (BF\% and BMI). ${ }^{11}$ This was done using Pearson coefficient correlation. The statistical analyzes were done by the multivariate regression analysis in conducting the determinant factors for the obesity parameters.

\section{RESULTS}

The general obesity parameters for sex and age were taken from 112 Telecommunication workers from the pool of randomly selected 138 participants. The 26 remaining didn't show up at the Charitas Hospital Medical Check Up clinic due to on leave out of town assignment, training outside Palembang. The demographic sample is $80 \%$ office workers and $20 \%$ technician.

Table 1 gives characteristic of the subjects (mean and standard deviation) based on sex and age versus the body weight $(\mathrm{kg})$, height $(\mathrm{cm})$, general obesity parameters as body mass index (BMI $\left.\mathrm{kg} / \mathrm{m}^{2}\right)$, body fat percentage, abdominal obesity (waist thigh-ratio (WT-ratio), waist hip-ratio - WH-ratio, waist circumference). ${ }^{12}$ 
Table 1 . The mean of obesity parameters based on age groups in men and women

\begin{tabular}{lcccc|cccc}
\hline & \multicolumn{4}{c}{ Men } & \multicolumn{3}{c}{ Women } \\
\cline { 2 - 8 } Age group & $\begin{array}{c}25 \\
(\mathrm{n}=21)\end{array}$ & $\begin{array}{c}35 \\
(\mathrm{n}=21)\end{array}$ & $\begin{array}{c}45 \\
(\mathrm{n}=32)\end{array}$ & $\begin{array}{c}55 \\
(\mathrm{n}=55)\end{array}$ & $\begin{array}{c}25 \\
(\mathrm{n}=3)\end{array}$ & $\begin{array}{c}35 \\
(\mathrm{n}=5)\end{array}$ & $\begin{array}{c}45 \\
(\mathrm{n}=16)\end{array}$ & $\begin{array}{c}55 \\
(\mathrm{n}=4)\end{array}$ \\
\hline BW $(\mathrm{kg})$ & $64.5 \pm 11.7$ & $57.1 \pm 9.9$ & $63.5 \pm 9.2$ & $61.5 \pm 11.7$ & $53.6 \pm 10.8$ & $51.8 \pm 6.7$ & $60.1 \pm 12.5$ & $61.3 \pm 12.9$ \\
Ht $(\mathrm{cm})$ & $163 \pm 8.4$ & $163.8 \pm 4.9$ & $163.6 \pm 3.4$ & $161.3 \pm 5.7$ & $153.3 \pm 4.0$ & $153.8 \pm 5.0$ & $154.2 \pm 5.6$ & $153.9 \pm 5.1$ \\
BMI $\left(\mathrm{kg} / \mathrm{m}^{2}\right)$ & $24.6 \pm 4.0$ & $21.2 \pm 3.3$ & $23.7 \pm 3.2$ & $23.4 \pm 3.6$ & $22.8 \pm 3.7$ & $22 \pm 3.5$ & $25.2 \pm 4.7$ & $25.9 \pm 4.8$ \\
BF (\%) & $23.9 \pm 7.0$ & $23.2 \pm 6.8$ & $26.3 \pm 5.8$ & $20.7 \pm 4.0$ & $24.6 \pm 6.6$ & $23.3 \pm 4.9$ & $27.3 \pm 5.5$ & $27 \pm 5.4$ \\
WT Ratio & $1.5 \pm 0.1$ & $1.5 \pm 0.2$ & $1.6 \pm 0.1$ & $1.5 \pm 0.1$ & $1.4 \pm 0.1$ & $1.5 \pm 0.1$ & $1.5 \pm 0.2$ & $1.5 \pm 0.1$ \\
WH Ratio & $0.9 \pm 0.1$ & $0.9 \pm 0.1$ & $0.9 \pm 0.1$ & $0.9 \pm 0.1$ & $0.9 \pm 0.1$ & $0.9 \pm 0.0$ & $0.9 \pm 0.1$ & $0.9 \pm 0.1$ \\
WC (cm) & $85 \pm 11.3$ & $78.3 \pm 10.9$ & $83.7 \pm 8.8$ & $80.2 \pm 9.5$ & $78.5 \pm 8.5$ & $83.1 \pm 7.0$ & $84.1 \pm 14.9$ & $85.0 \pm 15.4$ \\
\hline
\end{tabular}

Table 2. The mean of lipid profile based on age groups in men and women

\begin{tabular}{lcccc|cccc}
\hline Age Group & \multicolumn{4}{c}{ Men } & \multicolumn{4}{c}{ Women } \\
\cline { 2 - 9 } & $\begin{array}{c}25 \\
(\mathrm{n}=21)\end{array}$ & $\begin{array}{c}35 \\
(\mathrm{n}=21)\end{array}$ & $\begin{array}{c}45 \\
(\mathrm{n}=32)\end{array}$ & $\begin{array}{c}55 \\
(\mathrm{n}=55)\end{array}$ & $\begin{array}{c}25 \\
(\mathrm{n}=3)\end{array}$ & $\begin{array}{c}35 \\
(\mathrm{n}=5)\end{array}$ & $\begin{array}{c}45 \\
(\mathrm{n}=16)\end{array}$ & $\begin{array}{c}55 \\
(\mathrm{n}=4)\end{array}$ \\
\hline LDL-Chol (mg/dl) & $158.9 \pm 38.6$ & $137.8 \pm 37.1$ & $150.7 \pm 37.1$ & $156.6 \pm 32.7$ & $120.3 \pm 60.7$ & $162.6 \pm 43.1$ & $178.8 \pm 31.8$ & $194.3 \pm 5.4$ \\
HDL-Chol (mg/dl) & $44.0 \pm 10.7$ & $45.9 \pm 9.1$ & $47.7 \pm 8.9$ & $48.9 \pm 12.2$ & $52.7 \pm 6.4$ & $61.2 \pm 16.3$ & $62 \pm 15.4$ & $49.5 \pm 5.1$ \\
Cholesterol (mg/dl) & $232.1 \pm 45.9$ & $218.7 \pm 42.3$ & $231.5 \pm 37.0$ & $242.4 \pm 28.0$ & $200.0 \pm 52.0$ & $247.2 \pm 32.2$ & $266.8 \pm 30.9$ & $302.3 \pm 6.9$ \\
Triglyceride (mg/dl) & $174.2 \pm 49.4$ & $167.3 \pm 85.7$ & $166.4 \pm 77.6$ & $194.2 \pm 117.8$ & $67.7 \pm 14.6$ & $117.4 \pm 38.2$ & $182.4 \pm 52.9$ & $180.3 \pm 15.0$ \\
VLDL (mmol/l) & 0.6 & 0.7 & 0.7 & 0.7 & 0.4 & 0.5 & 0.8 & 0.6 \\
\hline
\end{tabular}

Table 3. The correlation between obesity parameters and lipid profiles in men and women

\begin{tabular}{cccc|cccc}
\hline \multirow{2}{*}{ Obesity Parameters } & \multicolumn{3}{c|}{ Men } & \multicolumn{3}{c}{ Women } \\
\cline { 2 - 7 } & LDL-Cholesterol & Cholesterol & Triglyceride & LDL-Cholesterol & Cholesterol & Triglyceride \\
\hline Body Fat Percentage & 0.087 & 0.171 & $0.273^{*}$ & $0.589 * *$ & $0.652^{* *}$ & $0.518^{* *}$ \\
Body Mass Index & 0.132 & $0.223^{*}$ & $0.344^{* *}$ & 0.371 & 0.401 & $0.483^{*}$ \\
Waist-Hip Ratio & 0.078 & $0.230^{*}$ & $0.543^{* *}$ & 0.115 & 0.004 & 0.271 \\
Waist-Thigh Ratio & $0.240^{*}$ & $0.300^{* *}$ & $0.337^{* *}$ & 0.187 & 0.109 & 0.328 \\
Waist Circumference & 0.141 & $0.229 *$ & $0.369^{* *}$ & 0.371 & 0.328 & $0.535^{*}$ \\
\hline
\end{tabular}

*Correlation is significant at the 0.01 level, **Correlation is significant at the 0.05 level 
Table 4. Determinant factor (lipid profiles) versus obesity parameters in men and women

\begin{tabular}{|c|c|c|c|c|c|c|}
\hline \multirow{2}{*}{ Obesity Parameters } & \multicolumn{3}{|c|}{ Men } & \multicolumn{3}{|c|}{ Women } \\
\hline & $\begin{array}{l}\text { Determinant } \\
\text { Factors }\end{array}$ & Adjusted r2 & $\mathrm{p}$ & $\begin{array}{l}\text { Determinant } \\
\text { Factors }\end{array}$ & Adjusted r2 & $\mathrm{p}$ \\
\hline $\mathrm{BF} \%$ & Triglyceride & 0.063 & $\mathrm{P}<0.012$ & Cholesterol & 0.402 & $\mathrm{P}<0.001$ \\
\hline BMI & Triglyceride & 0.108 & $\mathrm{P}<0.01$ & Triglyceride & 0.189 & $\mathrm{P}=0.036$ \\
\hline Waist - hip Ratio & Triglyceride & 0.286 & $\mathrm{P}<0.0001$ & - & - & - \\
\hline Waist - Thigh Ratio & $\begin{array}{c}\text { Triglyceride } \\
\text { LDL Cholesterol }\end{array}$ & 0.162 & $\mathrm{P}<0.0001$ & - & - & - \\
\hline Waist Circumference & Triglyceride & 0.162 & $\mathrm{P}<0.001$ & Triglyceride & 0.244 & $\mathrm{P}=0.018$ \\
\hline
\end{tabular}

Note : Dependent variables : obesity parameters; Independent variables : LDL cholesterol, cholesterol, trigyceride

The LDL cholesterol, cholesterol and triglyceride didn't show as a determinant factor for waist - hip ratio and waist thigh ratio in women.

All the lipid levels are positively associated with the obesity parameters. In general the lipid profile has strong correlation and as the determinant factors for the obesity is the triglyceride (Table 2-6). The association between the obesity measures and HDL cholesterol are inverse. In female the determinant factor for BMI and abdominal obesity parameters such as waist circumference is the triglyceride level. The association between BMI, BF\%, WH-ratio, WT-ratio, waist circumference and VLDL were positive. Male is higher than female except at the age group of 45 years.

The mean LDL cholesterol is higher in younger male compared to female. In the older female the mean of LDL cholesterol is higher than male. ${ }^{13}$ The mean of HDL cholesterol is lower in the younger male than female at the mean age of 25 years, the slanting line of male rising steadily to older age, while the female is higher in younger ages and remain high at 35 but drop steeply after 45 years.

The mean total of cholesterol is higher in younger male compared to female ( 25 years). After 35 years old female cholesterol level surpassed the male steadily until the retired age of 55 years old.

The mean of triglyceride levels given by younger age male is much higher than female, slightly lowering between 35 till 45 years old, but still higher than female. The peak triglyceride level of 45 years old female is higher than male and become lower after 55 years old.

The mean of VLDL cholesterol is positively associated with age and gender except the peak level on 45 years old of female group.

\section{DISCUSSION}

In this study, almost all associations between blood lipids and obesity appears to be different for each age group and gender. This result mainly seen clearly in the association between obesity and VLDL, total cholesterol and triglyceride, whereas the association among various obesity standard and HDL or LDL does not depend on age or gender. Even so all lipid profile depends on age and gender. Almost all study reports that mentioned effect has not been counted for. This could make the interpretation of the result is less accurate. In this study, the distinction between the association of the comprehensive obesity or abdominal obesity with lipid profile in the blood in the population of Kandatel (Telecom) employees has been examined.

The negative association between HDL and one kind of obesity standard appears to be nearly the same between female and male from various age groups. Even so, female group has higher HDL degree than male group and female from older age group has higher HDL degree than younger group. This result does not depend on the fact that female group is fatter than male group than younger age group.

Higher HDL degree possible related to the lower number of female with body fat concentrated in the stomach. This cannot describe the fact that HDL in older group of female is higher than younger group. Therefore, obesity possible has different impact for male and female from different age group. Besides that, almost all association between LDL and obesity does not depend on age and gender, and other study has reported that male has higher degree than female, except from 55 years age group, where female has higher degree. 
This study is cross sectional and therefore it cannot be used for studying the relation of cause and effect. Even so, there are some patterns that could not be used to describe the relationship among each variable. The association among various obesity standard and LDL or total cholesterol possibly indicates that the change in body composition emerges bigger change in younger people than the older and in male rather than female (there is an exception, it has not been found the association between waist thigh ratio and LDL in male). This result could possibly describe by stronger correlation between waist thigh ratio and intra abdominal fat in female rather than male. ${ }^{14}$ Therefore, even the young group is slimmer than the old group, the association between obesity and total cholesterol appears to be stronger in the young rather than the old. Almost no relationship between body composition and total cholesterol in older age group in female or male. Bivariation association among various obesity standard and fat is strengthened by a lot of diet which is contain fats and lack of activities. The available data cannot explain how far I $s$ the effect of these factors in the association which depends on age. Therefore, difference in the slanting line related to age could not be clarified by the result of this study. On the other hand in the paper by Rothan in 1976, the strongest association will be seen more clearly in the younger because other factors are not as many as older generation. ${ }^{15}$ Besides that, the reduction of one factor is more useful in the young people. Study from Hubert reports that the prevention of the increase of body weight in the young age is very useful in preventing heart disease particularly in male which generally more sensitive than female towards the change of body weight. ${ }^{16}$

As in this study, all study found a few or no association between obesity and LDL or total cholesterol.

The association between obesity and VLDL or triglyceride in female with the of 45 years is a little bit strange bat maybe it is caused by the influence of change in hormone and this places female at higher risk. ${ }^{17}$ One thing which more strange is that the weakest association between abdominal obesity and lipid profile is found in male of 45 years age group which constitutes group with the highest risk to get heart disease. The reason for this finding is difficult to comprehend.

The study using cross-sectional design, only the change of blood lipid levels among groups of participants which could be compared. This study could not examine the change of lipid levels in each individual related to gender and the change of age. This should be counted for when interpreting the available data. Even so, the obtained information on possible effects of changes in obesity may be informative is very useful.

Other studies have founded that stomach obesity frequently associated with the increase risk of heart disease. This shows the importance of avoiding concentrated obesity in the abdomen. Wadden reports that the decrease of mass body fat to the amount of $18.8 \%$ result in the decrease of body weight to the amount of $11,9 \mathrm{~kg}$, is associated as the decrease of waist hip ratio to the amount of $1.2 \%$ but the decrease of waist circumference to the amount of $8.3 \%{ }^{18}$ Even so, many studies found that the effect of sports, non smoking, unstable body weight, and hormone in the change of abdominal obesity, there is no factor can cause change by itself in various obesity standard.

Effect of obesity change to HDL, LDL or total cholesterol appears less compared to the effect to VLDL or triglyceride. The change of VLDL or triglyceride as compared to the change of HDL, LDL or total cholesterol is higher in various obesity standard (waist hip ratio, waist thigh ratio or waist circumference) than various obesity standard as a whole $(\mathrm{BF}, \mathrm{BF} \%$, or BMI). In accordance with Seidell, this study indicates that abdominal obesity more influence VLDL value or triglyceride, but obesity as a whole possibly influence all lipid profile evenly. ${ }^{19,20}$ Even though it is only speculation for the present time, this trend could be studied further in longitudinal study.

In the analysis of association between obesity and fat profile in the blood, some efforts had been made to obtain samples which represent Kandatel employees with the age of $25,35,45$, and 55 years. In general, we have succeeded in selecting samples of participants representing age group in body weight and BMI, while for the lipid level in blood there are some inconsistency. Therefore, we consider the participants of this study had adequately represented the population of Telecommunication employees with the age of $25-$ 55 years.

The present study analyzed cross sectional data and thus reflects only the subjects current effect of age and sex on the association between lipid profile and obesity among telecommunication workers in Palembang. The other effects on other aspects of control obesity such as lipoprotein, job vacation and physical activities will be done on other studies due to lack of 
our laboratory facilities. This study should be done further on larger sample sizes and including the other parameters.

Other factors like lipoprotein, workload and physical activities are not included in this studies due to laboratory facilities. The focus only on the effect of age and sex on the association between lipid profile and obesity.

\section{CONCLUSION}

The result of the analysis above indicates that almost all association between obesity and fat profile in blood is influenced by gender and age. The failure to consider these factors possibly cause subjectivity and the conclusion which is not accurate about the association of two variable between obesity and blood lipids, and possibly caused the population of this study could not be compared. Abdominal obesity possibly has bigger effect in VLDL, triglyceride, whereas obesity as a whole influenced HDL, LDL, VLDL, total cholesterol and triglyceride evenly.

\section{REFERENCES}

1. Haapale I, Hirvonen A, Niskanen L, et al. Anthropometry, bioelectrical impedance and dual energy x-ray absorptiometry in the assessment of body composition in elderly Finnish women. Clin Physiol Funct Imaging. 2002;383-91.

2. Tai ES, Lau TN, Ho SC, Fok ACK and Tan CE, Body fat distribution and cardiovascular risk in normal weight women. Associations with insulin resistance, lipids and plasma leptin. Int J Obesity. 2000; 24,751-7.

3. Paccaud F, Fasmeyer VS, Wietlisbach V, Bovet P. Dyslipidemia and abdominal obesity: an assessment in three general populations. J Clin Epidemiol. 2000;53:393-400.

4. Bertsias G, Mammas I, Linardakis M, Kafatos A. Overweight and obesity in relation to cardiovascular disease risk factors among medical students in Crete, Greece. BMC Public Health. 2003;3:1-9.

5. Freedman DS. Jacobsen SJ, Barboriak JJ, Sobocinski KA, Anderson AJ, Kissebah Ah, Sasse EA, Gruchow HW, Body fat distribution and male/ female differences in lipids and lipoproteins, Circulation. 1990;81;1498-1506.

6. WHO. Measuring obesity- classification and description of anthropometric data. Report on WHO consultation on the epidemiology of Obesity, Warsaw , 21-23 October 1987.
Nutrition Unit Document. EURACP/NUT 125. WHO Compenhagen: 1989

7. Pennock BE. Sensitivity of bioelectrical impedance to detect changes in human body composition. J Appl Physiol. 1990;68:2246-7.

8. O'Brien C, Young AJ, Sawka MN. Bioelectrical impedance to estimate changes in hydration status. Int $\mathrm{J}$ Sports Med. 2002;23:361-6.

9. Schools AMWJ, Dingemans AMC, Soeters PB, Wounters EFM. Within-day variation of bioelectrical resistance measurements in patients with chronic obstructive pulmonary disease. Clin Nutr. 1990;9:226-71.

10. Friedewald WT, Levy RI, Fredrickson DS. Estimation of the concentration of low-density lipoprotein cholesterol in plasma, without use of preparative ultra centrifuge. Clin Chem. 1972;18:499-502.

11. Stevens J, Cai J, Evenson KR, Thomas R. Fitness and fatness as predictors of mortality from all causes and from cardiovascular disease in men and women in the lipid research clinics study. Am J Epidemiol. 2002;156:832-41.

12. Seidell JC, Cigolini M, Charzewska J, Ellsinger B-M, Di Biase G. Fat distribution in Europe women: a comparison of anthropometric measurements in relation to cardiovascular risk factors. Int J Epidemiol. 1990;19:303-8.

13. Soler JT, Folsom AR, Kaye SA, Paneas RJ, Associations of abdominal adiposity, fasting insulin, sex hormone binding globulin, and estrone with lipids and lipoproteins in postmenopausal women, Athetoselorosis. 1989;79,21-7.

14. Jequier E. Pathways to obesity. Int J. Obes Related Metabolic Disorder 2002; 26(suppl):512-7.

15. Rothan KJ. Causes. Am J Epidemiology. 1976;104:567-92.

16. Hubert HB, Feinleib M, McNamara PM, Castelli WP. Obesity as an independent risk factor for cardiovascular disease: a 26-year follow-up of participants in the Framingham Heart Study, Circulation. 1983;67:968-77.

17. Soler JT, Folsom AR, Kusht LH. Prineas RJ, Seal US. Association of body fat distribution with plasma lipids, lipoprotein, apolipoproteins $\mathrm{Al}$ and $\mathrm{B}$ in post menopausal women. J Clin Epidemiol. 1988;41:1075-81.

18. Wadden TA, Stunkard AJ, Johnston FE, Wang J Pierson RN, Van Itallic TB, Costello E. Pena M. Body fat deposition in adult obese women. Il Changes in fat distribution accompanying weight reduction. Am J Clin Nutr. 1988; 47:229-34.

19. Seidell JC, Cigolini M, Charzewska J, Ellsinger B-M, \& Di Biase G, Bjorntorp P, Hautvay JGAJ, Contaldo F, Szostak $\mathrm{V}$, Seuro LA. Indicators of fat distribution, serum lipids and blood pressure in European women born in 1948- The European Fat Distribution Study. Am J Epidemiol. 1989; 130:53-65.

20. Seidell JC, Cigolini M, Charzewska J, Ellsinger B-M, Di Biase G. Fat distribution in Europe women: a comparison of anthropometric measurements in relation to cardiovascular risk factors. Int J Epidemiol. 1990;19:303-8. 